\title{
Application of hair-mercury analysis to determine the impact of a seafood advisory
}

\section{Citation}

Weihe, Pál, Philippe Grandjean, and Poul J. Jørgensen. 2005. “Application of Hair-Mercury Analysis to Determine the Impact of a Seafood Advisory." Environmental Research 97 (2) (February): 201-208. doi:10.1016/j.envres.2004.01.006.

\section{Published Version}

doi:10.1016/j.envres.2004.01.006

\section{Permanent link}

http://nrs.harvard.edu/urn-3:HUL.InstRepos:34786607

\section{Terms of Use}

This article was downloaded from Harvard University's DASH repository, and is made available under the terms and conditions applicable to Other Posted Material, as set forth at http:// nrs.harvard.edu/urn-3:HUL.InstRepos:dash.current.terms-of-use\#LAA

\section{Share Your Story}

The Harvard community has made this article openly available.

Please share how this access benefits you. Submit a story.

\section{Accessibility}


Manuscript submitted to Environmental Research (special issue on fish advisories)

Revision, 22 December, 2003

\section{Application of Hair-Mercury Analysis \\ to Determine the Impact of a}

\section{Seafood Advisory}

PAL WEIHE ${ }^{* \dagger}{ }^{*}$ PHILIPPE GRANDJEAN, ${ }^{\dagger+1}$ POUL J JØRGENSEN ${ }^{\S}$

*Faroese Hospital System, FR-100 Tórshavn, Faroe Islands; ${ }^{\dagger}$ Institute of Public Health, University of Southern Denmark, DK-5000 Odense, Denmark; ${ }^{\star}$ Department of Environmental Health, Harvard School of Public Health, Boston, MA 02115, USA; ${ }^{\S}$ Institute of Clinical Research, Odense University Hospital, DK-5000 Odense, Denmark

${ }^{1}$ To whom correspondence should be addressed at Institute of Public Health, University of Southern Denmark, Winslowparken 17, DK-5000 Odense, Denmark. Phone: +45-6650.3768. Fax: +45-6591.1458. E-mail: pgrand@health.sdu.dk 
Abstract: Following an official recommendation in the Faroe Islands that women should abstain from eating mercury-contaminated pilot whale meat, a survey was carried out to obtain information on dietary habits and hair samples for mercury analysis. A letter was sent to all 1180 women aged 26-30 years who resided within the Faroes, and the women were contacted again one year later. A total of 415 women responded to the first letter; the second letter resulted in 145 repeat hair samples and 125 new responses. Questionnaire results showed that Faroese women, on average, consumed whale meat for dinner only once every second month, but the frequency and meal size depended on the availability of whale in the community. The geometric mean hair-mercury concentration at the first survey was higher in districts with available whale than in those without $(3.03 \mu \mathrm{g} / \mathrm{g}$ vs. $1.88 \mu \mathrm{g} / \mathrm{g} ; \mathrm{p}=0.001)$. The mercury concentration also depended on the frequency of whale meat dinners and on consumption of dried whale meat. The 36 women who did not eat whale meat at all had a geometric mean hair-mercury concentration of $1.28 \mu \mathrm{g} / \mathrm{g}$. At the time of the second survey, the geometric mean had decreased to $1.77 \mu \mathrm{g} / \mathrm{g}$ ( $\mathrm{p}<$ 0.001), although whale was now available in all districts. In comparison with previously published data on hair-mercury concentrations in pregnant Faroese women, these results document substantially lower exposures as well as a further decrease temporally associated with the issue of a stricter dietary advisory.

Key words: Biological monitoring Intervention study Methylmercury Pilot whales Risk management 


\section{FUNDING SOURCES}

This study was supported by a grant from the Danish Medical Research Council. The study was carried out in accordance with the Helsinki convention and with the approval of the ethical review committee for the Faroe Islands. 


\section{INTRODUCTION}

Dietary recommendations are usually issued without any subsequent assessment of their impact. Therefore, little information is available on factors that affect compliance. In regard to some food contaminants, exposure markers constitute an objective and powerful instrument to assess individual intake levels (Grandjean et al., 1994). For example, exposure biomarker data have been critical for public policy decisions on abatement of contamination with lead (Annest et al., 1983) and methylmercury (Schober et al., 2003). In addition, knowledge of one's own exposure to a dietary contaminant could be an important incentive to changing food habits. Methylmercury exposure is almost always exclusively dietary and originates from certain types of freshwater fish and seafood (UNEP, 2002). For assessment of dietary intakes of this food contaminant, hairmercury analysis has been found to be highly suitable, though somewhat imprecise (Grandjean et al., 2002). Hair sampling does not require any expertise, the sample can be sent by regular mail, it may be stored at room temperature, and the relatively high mercury concentration allows a simple and rapid analysis by well-documented technology (Cerniciari et al., 1995; Grandjean, 1994).

In the Faroe Islands, the main single source of increased methylmercury exposure is whale meat (Andersen et al., 1989). Within this small fishing community in the North Atlantic, a new dietary recommendation was dispersed through news media and thereby reached all residents. To examine the impact of this advisory and to assess whether knowledge of one's own exposure might lead to changes in dietary habits, we contacted twice by mail an age-stratified group of the female population. Table 1 shows the time schedule of the main events of the study. 
Whaling in the Faroes

The North Atlantic pilot whale (Globicephala melas) has been hunted in several communities in the North Atlantic and is still harvested in the Faroes (Johansen et al., 1999). The Faroese pilot whale catch is a traditional, communal, environmentally sustainable, and non-commercial hunt. The authorities distribute the meat and blubber according to traditional rules, the main rule being equal shares for all inhabitants of the district.

The pilot whale catch proceeds as follows: a school of pilot whales, being observed near the coast, is driven into a fiord and beached, preferably on a gently sloping seashore. The whales are then killed by stabbing the neck with a special knife that severs the carotid arteries. Acknowledging the animal welfare issues, the Faroese authorities have updated the age-old rules laid down for the pilot whale hunt by banning the harpoon and the whale spear and by regulating the use of hooks from boats (Bloch et al., 1990).

The pilot whale is a small whale that occurs in large schools in the North Atlantic and the Mediterranean, and (as a closely related species) in the Pacific Ocean. As a small cetacean, this whale is not covered by regulations decided by the International Whaling Commission (IWC). Working jointly with the IWC, the International Council for the Exploration of the Sea, the North Atlantic Marine Mammal Co-operation Organisation, and other authorities, Faroese and international scientists keep a close watch on the size of the whale population. The most recent estimate is that there are approximately 780,000 animals in the North East Atlantic (Bloch et al., 1990).

Since 1584, Faroese civil servants have secured detailed reports on the pilot whale harvest, including the date of the catch, the location, the number of whales, the amount of meat and blubber of each whale, and the distribution of the catch to members of the local communities. The amount 
of meat and blubber is measured in skinn units, each consisting of $38 \mathrm{~kg}$ meat and $34 \mathrm{~kg}$ blubber. The statistics are incomplete before 1709, but subsequent reports show that the annual catch fluctuates around a long-term average catch of approximately 1,000 animals, or 6,000 skinn (Bloch et al., 1990). The Faroese authorities consider this harvest of pilot whales in the waters around the Faroe Islands as both sustainable and legitimate. Should the scientists so recommend, the authorities will be prepared to limit the catches (Bloch et al., 1990). So far, catches have been limited only in order to avoid waste when the need for whale meat and blubber is considered to be met in a particular district.

The distribution of the catch is administrated by the local head of police (Bloch et al., 1990). The meat and blubber are salted, frozen or cut in strips for drying. By these preservation procedures, the catch can be kept for many months, thereby ensuring a steady supply over time. Normally, storage time is expected to last up to one year, since pilot whale catches are seasonal and mostly occur in the late summer months. While fresh meat and blubber may be cooked hours or days after the catch, feasting ceremonies with unusual big consumption do not occur.

\section{Dietary advisories}

Since 1980, pregnant women have been advised to limit their consumption of pilot whale meat and blubber to avoid methylmercury exposure. A large study of women who gave birth at the Faroese hospitals in 1986-1987 showed that about $15 \%$ had hair-mercury concentrations above $10 \mu \mathrm{g} / \mathrm{g}$ (Grandjean et al., 1992), a level then considered the upper limit of safe exposure (IPCS, 1990). A subsequent recommendation in 1989 extended the advice to indicate that adults should not eat more than 150-200 grams of pilot whale meat (and 100-200 grams of blubber) per month. With a mercury concentration of about $2.1 \mu \mathrm{g} / \mathrm{g}$ whale meat, this intake would correspond 
to an average daily dose of $0.2 \mu \mathrm{g} / \mathrm{kg}$ body weight for a $60-\mathrm{kg}$ woman.

The children born in 1986-1987 were examined by sophisticated neuropsychological and neurophysiological methods at age 7 years, and the results showed significant exposureassociated decrements in several brain functions (Grandjean et al., 1997; Weihe et al., 1998). These results were presented and discussed at an international conference in 1998. In August 1998, the following diet recommendations were issued by the Faroese authorities, based on the demonstrated effects of mercury exposure and on a general assessment of PCB's: "The mercury content of pilot whale meat is high and is one of our main mercury sources. Therefore, we recommend that adults eat no more than one to two meals a month. Women who plan to become pregnant within three months, pregnant women, and nursing women should abstain from eating pilot whale meat. High PCB contents in blubber lead us to recommend that adults, at the maximum, eat pilot whale blubber once to twice a month. However, the best way to protect fetuses against the potential harmful effects of PCBs is if girls and women do not eat blubber until they have given birth to their children. Pilot whale liver and kidneys should not be eaten at all".

\section{MATERIALS AND METHODS}

Mailing addresses were obtained from the Faroese Public Registry for all women aged 26-30 years and residing in the Faroe Islands at the beginning of 1999. This 5-year age interval was chosen because of the peak prevalence of pregnancy at these ages at about $15 \%$. A letter of invitation in Faroese was sent to 1180 women from the Chief Physician of the Department of Occupational Medicine and Public Health of the Faroese Hospital System (PW). He informed them that mercury concentrations in pilot whale meat were high and repeated the most recent 
dietary advisory. A free hair analysis for mercury was offered and detailed instructions were given in Faroese on hair sampling: "cut the hair sample from the back of your head so that the total hair sample corresponds to the thickness of a match. The strands should be cut close to the scalp and be at least $6 \mathrm{~cm}$ long. To identify the direction that the hair had been growing, a cotton string provided in the enclosed envelope should be tied around the proximal end of the hair sample."

The letter also indicated that a safe exposure to mercury would correspond to a mercury concentration in hair that was below $5: \mathrm{g} / \mathrm{g}$, and that this exposure was of particular concern for women who were considering or planning to become pregnant in the future. A questionnaire in Faroese on dietary habits was also enclosed in the letter; an English translation is shown in Table 2. A stamped envelope was included in order to facilitate the return of the questionnaire and the hair sample.

All letters were mailed in February, 1999. A total of 415 women answered the questionnaire and 412 of those supplied a hair sample, 24 of which were not appropriate for analysis. The three women who had filled in the questionnaire but not supplied a hair sample were contacted again, but none responded.

In March, 2000, a second invitation to send in hair samples was sent to all of the 415 women who had initially responded; 159 (38.3\%) repeat responses were received. At the same time, the 765 non-responders received a separate letter of invitation; a total of $125(16.3 \%)$ new subjects now answered the questionnaire and 122 of them provided a hair sample. The total response rate was $24.1 \%(\mathrm{~N}=284)$. Undoubtedly, the response rate was negatively affected by a concomitant discussion in the media on privacy of health data, provoked by the formation of a 
population genetics data base in Iceland.

The proximal $2 \mathrm{~cm}$ of each hair sample from both the first and the second survey were analyzed for mercury as an indicator of methylmercury exposure during the recent months (Grandjean et al., 2002). Assuming a hair growth rate of $1 \mathrm{~cm}$ per month, a distal segment 6-8 $\mathrm{cm}$ measured from the proximal end of the first sample would correspond to the time before the official advisory; a total of 320 samples were of sufficient length for this purpose. Only 63 of the first hair samples allowed analysis of hair at $11-13 \mathrm{~cm}$ that would have formed about a year before.

The intent was to report the first results to all women within a few months, but problems with the analytical instrument delayed the initiation of the assays so that the average reporting time was six months. Results reported before October of 1999 were accepted as timely in regard to changes in dietary habits that could be assessed in the second samples.

The hair samples were analyzed in segments as described above. Mercury analysis was performed by atomic absorption spectrometry (Grandjean et al., 2002). For mineralization of the sample, we used microwave digestion in PTFE-lined vessels and mercury analysis by flowinjection cold-vapor atomic absorption spectrometry. The total analytical imprecision was estimated to be 2.3 and $3.2 \%$ at mercury concentrations 4.7 and $11.4: \mathrm{g} / \mathrm{g}$ respectively. The accuracy of the mercury determination in human hair was ensured by using the certified reference material CRM 397 (BCR, Brussels, Belgium) as quality control material; the mercury concentration averaged $11.36: \mathrm{g} / \mathrm{g}$ compared to the assigned value of $11.93 \pm 0.77: \mathrm{g} / \mathrm{g}$. Participation in external quality assessment schemes also rendered highly satisfactory results.

To ascertain individual exposure potentials, the official statistics on pilot whale catches 
were consulted. The catches in both 1998 and 1999 were similar to the historical average (6002 skinns and 5398 skinns, respectively), but the locations of the catches differed. From the residence of each responder, and the date and size of the most recent local whale catch, it was determined whether whale meat had been available during the period of time reflected by each hair segment analyzed. The following assumptions were made: 1) The amount of whale meat allocated to a community by the authorities after a whale catch is evenly distributed to all residents of the community and 2) The individual consumption of whale meat (when available) averages $12 \mathrm{~g}$ per day, as documented in the most recent dietary survey (Vestergaard and Zachariassen,1987). Seven women had recently moved and their exposure potential could therefore not be classified.

Because of skewed distributions, hair-mercury results were logarithmically transformed to calculate geometric means. Parametric tests included paired and unpaired $\mathrm{t}$ tests. Questionnaire answers were grouped, where appropriate, to obtain groups that were no smaller than $5 \%$. A regression analysis was carried out by using as independent variables the questionnaire answers that were significant $(\mathrm{p}<0.05)$ predictors in bivariate analyses.

\section{RESULTS}

A questionnaire answers from the 415 women from the first survey and 125 from the second survey differed little and were therefore combined (Table 2). A total of 126 (24.3\%) women did not eat pilot whale at all, but some ate pilot whale as often as nine times per month (twice a week). The median frequency was once every two months. The average portion size was between $100 \mathrm{~g}$ and $200 \mathrm{~g}$. Again, assuming a methylmercury concentration of $2.1: \mathrm{g} / \mathrm{g}$ (Andersen 
et al., 1987) and a body weight of $60 \mathrm{~kg}$, a whale meat stake of $150 \mathrm{~g}$ once every two months corresponds to an average daily intake of methylmercury at slightly below $0.1: \mathrm{g} / \mathrm{kg}$ body weight. This intake level would result in a hair-mercury concentration of approximately $1: \mathrm{g} / \mathrm{g}$ (UNEP, 2002). Dried pilot whale meat probably also contributed to the total intake, although the majority of the women ate this food item only rarely. However, the questionnaire did not aim at providing quantifiable data in regards to other mercury-containing food sources, such as seabirds and fish, which were also likely to contribute to the exposure. Most questionnaire results were similar in districts with and without local availability of whale, but the frequencies of whale dinners and the sizes of portions were lower when whale meat was not considered to be locally available.

The geometric mean mercury concentration in the 388 hair samples from the first survey was $2.53: \mathrm{g} / \mathrm{g}$. The 238 women who had resided in districts where whale meat was available showed a higher mean of $3.03: \mathrm{g} / \mathrm{g}$ [i.e., about $60 \%$ greater than the geometric mean of 1.88 $: \mathrm{g} / \mathrm{g}$ seen in the 144 women from districts without local access to whale meat $(\mathrm{p}=0.001)]$. Also, hair-mercury concentrations were greater in the smaller fishing villages, as compared to the three major towns, but this tendency was probably due to the relative lack of local access to whale in the towns. Higher mercury levels were also seen in women who had not decreased their intake of whale (Table 4). The mercury level was associated with the frequency of whale meat dinners, the size of whale meat portions, and with habitual intake of dried whale meat. At the same time, inclusion of seabirds in the diet was associated with an increase, while inclusion of meat from terrestrial animals was associated with a decrease in hair-mercury concentrations.

For the 36 women who neither ate whale meat for dinner nor dried whale meat, the 
average hair-mercury concentration was only $1.28: \mathrm{g} / \mathrm{g}$. Slightly increased concentrations were seen in women, who planned the dinner meals well in advance. A similar increase was seen in women who cared about the meals being nutritious, in accordance with the widespread belief that eating whale is healthy. Yet, only in regards to women without local access to whale meat did the desire for more information about diet and health show a tendency of increased mercury exposure. A regression analysis was carried out with the hair-mercury concentration as the dependent variable and with all predictors as independent variables that had been found statistically significant $(\mathrm{p}<0.05)$ in the bivariate analyses. This analysis showed that the main determinants of the hair mercury level were survey number, availability of whale meat and frequency of whale meat dinners, while all other predictors were non-significant. These findings are in accordance with the expectation, but the low participation rate precluded more detailed analysis of the data.

The geometric mean of the $6-8 \mathrm{~cm}$ sample from the first survey was $2.63: \mathrm{g} / \mathrm{g}$, which is marginally $(\mathrm{p}=0.05)$ higher than the $2.46: \mathrm{g} / \mathrm{g}$ seen in the same women's proximal segment about 6 months later. Thus, these women had barely reduced their exposures during the first few months following the new advisory. The hair-mercury profile from 46 women, from whom three segmental analyses were available, also did not show any significant temporal pattern.

At the time of the second survey, whale meat was considered available in all districts involved, but the geometric mean had nonetheless decreased to $1.77: \mathrm{g} / \mathrm{g}$. This temporal lowering of hair-mercury concentrations was seen both in the total material and in the restricted group of women, who had local access to whale on both occasions $(\mathrm{p}<0.001)$. For the 145 women, who had a hair analysis on both occasions, the geometric means were $2.49: \mathrm{g} / \mathrm{g}$ and 
$1.83: \mathrm{g} / \mathrm{g}$, respectively $(\mathrm{p}<0.001)$. If based only on the 88 of the women residing in districts with easy access to whale meat at both occasions, the decrease from the first to the second survey was also clear $(\mathrm{p}<0.001)$. Despite the decreases observed, the results from women who participated in both surveys correlated well $(\mathrm{r}=0.59)$. The averages for the women examined twice were similar to those of the total groups.

Most of the women had received the result of the (first) hair analysis in time so that a change in dietary habits could be reflected in the mercury concentration of the second hair sample $(\mathrm{N}=95)$. Whether they responded to the second invitation letter did not seem to be related to the time when they received the hair-analysis $\left(\mathbf{P}^{2}=0.126 ; p=0.72\right)$. However, the availability of an early report on their hair level on the first survey did not seem to affect the result of the second survey, perhaps because the delay in reporting the hair analyses left only limited time to detect any dietary change.

\section{DISCUSSION}

Published exposure levels from the Faroes are similar in magnitude to those occurring in Arctic areas and in other populations that rely heavily on seafood, including marine mammals (UNEP, 2002). The present study of women in reproductive age groups, a life-stage group considered particularly at risk (UNEP, 2002), demonstrates the feasibility of obtaining hair samples by mail for mercury analysis. The hair-mercury concentrations showed clear associations with factors that would be expected to influence the exposure potential.

The statistically significant decrease from the first survey to the second coincides with the dietary recommendation from the Faroese health authorities that women in reproductive age groups should refrain from eating pilot whale meat. The public advisory was the result of serious 
considerations that took into regard the essential nutrients in whale meat, and the historical and cultural importance of pilot whales and whaling.

Still, this fortunate change in exposure levels may not necessarily be ascribed to a single advisory. The impact of previous dietary advisories and press coverage of mercury toxicity are probably reflected by the fact that, at the first survey, almost half of the women said that they had already decreased their whale consumption, and only $16 \%$ ate whale meat for dinner more frequently than the recommended rate of once per month. While hair-mercury concentrations appeared to be relatively constant during the last 6-12 months before the first survey, the reduction seen in the 125 women who participated in the survey one year later was unlikely to be due to chance. In addition, this substantial reduction occurred despite a wider availability of whale meat in the communities.

Due to the limited response rate, it is possible that the women are not representative of the total eligible female population. Nonetheless, the association with whale intake is similar to the one found in a cohort of consecutive births in 1986-1987 (Grandjean et al., 1992), and the overall survey results show lower averages, also in comparison to the more recent birth cohort data from 1994-1995 (Steuerwald et al., 2000). Women who responded may have had special reason for concern (e.g., because they frequently ate pilot whale meat, or because they were or planned to become pregnant). In addition, women who for some reason had already decreased their whale meat intake might be interested in having their low exposure confirmed. For privacy reasons, the results could not be linked to medical information on pregnancies and child births. Because pregnant women are probably more likely to abstain from eating whale meat, the fact that the present results are now lower than previous results from pregnant women, would support the conclusion that the decreases in exposure are real. 
Given the increased concerns about methylmercury toxicity (UNEP, 2002), the long-term aim of the most recent dietary advisory is to reduce hair-mercury concentrations in women in reproductive age groups to $1-2: \mathrm{g} / \mathrm{g}$ and below. This mercury level appears to correspond to the baseline exposure that will, almost by necessity, occur due to prevalent, but low methylmercury concentrations in fish, shellfish, and seabirds. Therefore, the women who completely abstained from eating whale meat had hair-mercury concentrations in the desired range. In this regard, the current recommendation seems to be appropriate.

The use of exposure biomarkers for preventive purposes is not new in environmental health. Yet, most experience has centered on blood-lead assessment, where this exposure biomarker has been an important outcome variable in many intervention studies (Aschengrau et al., 1994; Hilts et al., 1998; Lanphear et al., 1999). In a wider sense, the use of personal clinicalchemistry results is well established in clinical management of certain diseases, especially serum-glucose monitoring in diabetes patients (Cox et al., 1991; Larsen et al., 1990). Also, cholesterol screening has a long history in the prevention of cardiovascular disease, because a serum result deemed disadvantageous motivates the subject to pursue available means to remain healthy (Elton et al., 1994; Reynolds et al., 1997; Strychnar et al., 1997). The present study lends further support to the use of exposure biomarkers for individual prevention purposes. Still, because of the small numbers involved and the delay in reporting the hair-mercury results, we could not determine whether the hair-mercury result affected the women's dietary habits.

In conclusion, the impact of a dietary recommendation issued by the Faroese authorities was examined by means of hair-mercury analyses. While only a small decrease was observed in the months prior to the advisory, a $60 \%$ decrease occurred during the year following this recommendation. Although the material is small and may not necessarily be representative, this 
finding supports the usefulness of a public information campaign with a relatively simple message in regard to seafood contamination, and it supports the use of hair-mercury assessments for follow-up of the intervention. The decisions made by the Faroese public health authorities in regard to dietary recommendations therefore appear both appropriate and successful.

\section{ACKNOWLEDGMENTS}

We are grateful to Elsa Olsen for maintaining the subject files, to Brita Andersen for conducting the hair analyses, and to Julie Watts for her comments on the questionnaire.

\section{REFERENCES}

Andersen, A., Juhlshamn, K., Ringdal, O., and Mørkøre, J., 1987 Trace elements intake in the Faroe Islands II. Intake of mercury and other elements by consumption of pilot whales

(Globicephalus meleanus). Sci. Total Environ. 65, 63-68.

Annest, J.L., Pirkle, J.L., Makuc, D., Neese, J.W., Bayse, D.D., Kovar, M.G., 1983.

Chronological trend in blood lead levels between 1976 and 1980. N. Engl. J. Med. 308, 13731377.

Aschengrau, A., Beiser, A., Bellinger, D., Copenhafer, D., and Weitzman, M., 1994. The impact of soil lead abatement on urban children's blood lead levels: phase II results from the Boston Lead-In-Soil Demonstration Project. Environ. Res. 67, 125-148.

Bloch, D., Desportes, G., Hoydal, K., and Jean, P., 1990. Pilot Whaling in the Faroe Islands, July 1986-July 1988. North Atlantic Studies 2, 36-44.

Bloch, D., Hoydal, K., Joensen, J.S., and Zachariassen, P., 1990. The Faroese Catch of the LongFinned Pilot Whale. Bias shown of the 280 year time series. North Atlantic Studies 2, 
$45-46$.

Cernichiari, E., Toribara, T.Y., Liang, L., Marsh, D.O., Berlin, M, Myers, G.J., Cox, C., Shamlaye, C.F., Choisy, O., Davidson, P.W, Clarkson, T.W., 1995. The biological monitoring of mercury in the Seychelles study. Neurotoxicology 16, 613-628.

Cox, D.J., Gonder_Frederick, L., Julian, D., Cryer, P., Lee, J.H., Richards, F.E., and Clarke, W., 1991. Intensive versus standard blood glucose awareness training (BGAT) with insulindependent diabetes: mechanisms and ancillary effects. Psychosom. Med. 53, 453-462.

Elton, P.J., Ryman, A., Hammer, M., and Page, F., 1994. Randomized controlled trial in northern England of the effect of a person knowing their own serum cholesterol concentration.

J. Epidemiol. Community Health 48, 22-25.

Ginsberg GL, Toal BF, 2000 Development of a single-meal fish consumption advisory for methyl mercury. Risk Anal. 20, 41-47.

Grandjean, P., Brown, S., Reavey, P., and Young, D., 1994. Biomarkers of chemical exposure: state of the art. Clin Chem 40, 1360-1362.

Grandjean, P., Jørgensen, P.J., Weihe, P., 2002. Validity of mercury exposure biomarkers. In: Wilson SH, Suk WA, Eds. Biomarkers of Environmentally Associated Disease. CRC Press/Lewis Publishers, Boca Raton, FL, pp. 235-247.

Grandjean, P., Weihe, P., Jørgensen, P.J., Clarkson, T., Cernichiari, E., and Viderø, T., 1992. Impact of maternal seafood diet on fetal exposure to mercury, selenium, and lead. Arch. Environ. Health 47, 185-195.

Grandjean, P., Weihe, P., and Nielsen, J.B., 1994. Methylmercury: Significance of intrauterine and postnatal exposures. Clin. Chem. 40, 1395-1400.

Grandjean, P., Weihe, P., White, R.F., Debes, F., Araki, S., Murata, K., Sørensen, N., Dahl, D., Yokoyama, K., Jørgensen, P.J., 1997. Cognitive deficit in 7-year-old children with prenatal 
exposure to methylmercury. Neurotoxicol. Teratol. 19, 417-428.

Hilts, S.R., Bock, S.E., Oke, T.L., Yates, C.L., and Copes, R.A., 1998. Effect of interventions on children's blood lead levels. Environ. Health Perspect. 106, 79-83.

IPCS (International Programme on Chemical Safety), 1990. Methylmercury (Environmental Health Criteria 101). Geneva: World Health Organization.

Lanphear, B.P., Howard, C., Eberly, S., Auinger, P., Kolassa, J., Weitzman, M., Schaffer, S.J., and Alexander, K., 1999. Primary prevention of childhood lead exposure: A randomized trial of dust control. Pediatrics 103, 772-777.

Larsen, M.L., Horder, M., and Mogensen, E.F., 1990 Effect of long-term monitoring of glycosylated hemoglobin levels in insulin-dependent diabetes mellitus. N. Engl. J. Med. 323, 1021-1025.

Lyketsos, C.G., 2003. Should pregnant women avoid eating fish? Lessons from the Seychelles. Lancet 361, 1667-1668.

Johansen, T. , Olafsson, A., 1999. The Faroe Islands: A Brief Introduction. Faroese Government Office, Copenhagen.

Reynolds, K.D., Gillum, J.L., Hyman, D.J., Byers, T., Moore, S.A., Paradis, G., Flora, J.A., and Lazarus, K., 1997. Comparing two strategies to modify dietary behavior and serum cholesterol. J. Cardiovasc. Risk 4, 1-5.

Schober, S.E., Sinks, T.H., Jones, R.L., Bolger, P.M., McDowell, M., Osterloh, J., Garrett, E.S., Canady, R.A., Dillon, C.F., Sun, Y., Joseph, C.B., Mahaffey, K.R., 2003. Blood mercury levels in US children and women of childbearing age, 1999-2000. JAMA. 289, 1667-1674.

Schultz, B., Pawel, D., and Murphy, A., 1999. A retrospective examination of in-home educational visits to reduce childhood lead levels. Environ. Res. 80, 364-368.

Steuerwald, U., Weihe, P., Jørgensen, P.J., Bjerve, K., Brock, J., Heinzow, B., Budtz-Jørgensen, 
E., and Grandjean, P., 2000. Maternal seafood diet, methylmercury exposure, and neonatal neurological function. J. Pediatr. 136, 599-605.

Strychar, I.M., Champagne, F., Ghadirian, P., Bonin, A., Jenicek, M., and Lasater, T.M., 1998. Impact of receiving blood cholesterol test results on dietary change. Am. J. Prev. Med. 14, $103-110$

UNEP, 2002. Global Mercury Assessment, United Nations Environment Programme. Geneva: UNEP, 2002. Available from URL:

http://www.chem.unep.ch/mercury/Report/Final\%20Assessment\%20report.htm (Accessed, August 10, 2003).

Vestergaard, T. and Zachariassen, P., 1987. Dietary survey 1981-82. Fróðskaparrit 33,5-18 Weihe, P., Grandjean, P., Debes, F., White, R., 1996. Health implications for Faroe Islanders of heavy metals and PCBs from pilot whales. Sci. Tot. Environ. 186, 141-148. 
TABLE 1

Calendar of events in intervention study

Time Event

November

1997

Scientific publication of study showing adverse health effects of prenatal mercury exposure in the Faroes

June

1998

International conference on mercury and human health convened in the Faroes

August

1998

Dietary advisory issued by Faroese health authorities

January

1999

First letter to 1180 women requesting hair sample and

questionnaire

July- October $1999 \quad$ Results reported

March 2000

Second letter requesting second hair sample from responders;

Letter to previous non-responders requesting hair sample and questionnaire

October $\quad 2000-\quad$ Results reported

January $\quad 2001$ 
TABLE 2

Results of questionnaire responses from 540 women (percentages based on subjects responding to the question)

Question $\mathrm{N}(\%)$

1. How far in advance do you usually decide what you will have for dinner?

I choose dinner the same day

I choose the dinner the day before

Two to three before

I plan one week ahead

$3 \quad(0.6)$

2. Do you eat about the same amount of whale meat and blubber as you did one year ago?

Yes, about the same amount of whale meat and blubber

No, I now eat more whale meat and blubber

Now I eat less whale meat and blubber

3. Is it in a fixed schedule, how often you eat whale meat?

Yes, iron cast

Yes, almost fixed

No, it depends on what is in storage

4. How many times per month, do you think you have eaten whale for dinner, on average, in the past six months?

$0.1-0.4$

$0.5-0.8$

$172(33.2)$

1.0 
5. How big was your portion on average?

$\begin{array}{ll}\text { Less than } 100 \mathrm{~g} & 38\end{array}$

About $100 \mathrm{~g}$

Between 100 and $200 \mathrm{~g}$

About $200 \mathrm{~g}$

Between 200 and $300 \mathrm{~g}$

$\geq 300 \mathrm{~g}$

6. Do you often eat dried whale meat?

Yes, for dinner

Yes, for supper

Yes, for dinner and supper

No, I do not eat dried whale meat at all

No, I only eat dried whale meat on rare occasions

7. Do you normally eat blubber with whale meat/or fish?

Yes, with whale meat

Yes, with fish

Yes, with both (fish and whale meat)

No, only on rare occasions

I do not eat blubber at all

$143 \quad(27.2)$

8. How many times per month, do you think you have eaten blubber for dinner, on average, in the past six months? 
$0.75-1$

9. How big was the portion on average?

Less than $100 \mathrm{~g}$

Between 100 and $200 \mathrm{~g}$

About $100 \mathrm{~g}$

About $200 \mathrm{~g}$

Between 200 and $300 \mathrm{~g}$

About $300 \mathrm{~g}$

More then $300 \mathrm{~g}$

10. Is it in a fixed schedule how often you eat fish?

Yes, iron cast

Yes, almost fixed

No, it varies

11. How often, per week, on average, have you eaten fish or fish products in the past six months?

0 
12. How often per month, on average, have you eaten fulmar in the past six months?

0

$1-1.5$

$>2.0$

13. How often per month on average, have you eaten other sea birds in the past six months?

0

$<1$

1

$>1$

38

14. How often per week, on average, have you eaten meat from land animals, including chicken?

$0-1$

$1.5-2$

$121 \quad(23.0)$

$2.5-3$

$189(36.0)$

$3.5-4$

$100 \quad(19.0)$

$>4$

$55(10.5)$

15. Do you consider the nutritional value of the food when you choose it for dinner?

Yes, normally I do

Yes, occasionally I do

$147 \quad(27.6)$

No, I rarely do

$157 \quad(29.5)$ 
16. Do you think about the environmental pollutants in the food when you choose it for dinner?

Yes, normally I do 99 (18.6)

Yes, occasionally I do $184(34.6)$

No, I rarely do $162(30.5)$

Never

17. Do you lack knowledge about the importance of the food for health?

Yes

No

18. How many adult people do you normally cook for at home?

3

18. How many children do you normally cook for at home?

0 
TABLE 3

Comparison of questionnaire responses from 415 women from first and 125 from the second survey.*

\begin{tabular}{llc}
\hline & First & Second \\
\hline
\end{tabular}

1. How far in advance do you usually decide what you will have for dinner?

$\begin{array}{lrrrr}\text { I choose dinner the same day } & 96 & (23.7) & 37 & (32.7) \\ \text { I choose dinner the day before } & 292 & (72.1) & 75 & (66.4) \\ \text { Two to three days before } & 15 & (3.7) & 0 & (0) \\ \text { I plan one week ahead } & 2 & (0.5) & 10 & (0.9)\end{array}$

2. Do you eat about the same amount of whale meat and blubber as you did one year ago?

$\begin{array}{lcccc}\text { No, I eat less } & 182 & (45.5) & 44 & (42.7) \\ \text { Yes, about the same } & 207 & (51.8) & 58 & (56.3) \\ \text { No, more } & 11 & (2.8) & 1 & (1.0)\end{array}$

3. How many times per month, do you think you have eaten whale for dinner, on average, in the past six months?
0
$86 \quad(21.7) \quad 40 \quad(33.1)$
$0.1-0.4$
$33 \quad(8.4) \quad 9 \quad(7.4)$
$0.5-0.75$
$135 \quad(34.0) \quad 37 \quad(30.6)$
1.0
$69 \quad(17.4) \quad 26 \quad(21.5)$
$1.5-2$
$56 \quad(14.1) \quad 4$
$>3$
$18 \quad(4.6) \quad 5$ 
4. How big was your portion on average?

Less than $100 \mathrm{~g}$

About $100 \mathrm{~g}$

Between 100 and $200 \mathrm{~g}$

About $200 \mathrm{~g}$

Between 200 and $300 \mathrm{~g}$

$\geq 300 \mathrm{~g}$

5. Do you often eat dried whale meat?

Yes, for dinner/supper

No, I only eat dried whale meat on rare occasion

No, I do not eat dried whale meat at all

$\begin{array}{rrrr}25 & (6.2) & 13 & (13.8) \\ 86 & (25.0) & 25 & (26.6) \\ 120 & (34.9) & 30 & (31.9) \\ 60 & (17.4) & 15 & (16.0) \\ 30 & (8.7) & 7 & (7.4) \\ 16 & (3.9) & 4 & (4.2)\end{array}$

$\begin{array}{llll}25 & (6.2) \quad 3 & (2.4)\end{array}$

$244 \quad(59.8) \quad 73 \quad(59.3)$

$139 \quad(34.1) \quad 47 \quad(38.2)$

* Selected questions where $\mathrm{p}<0.05$ by analysis of variance 
TABLE 4

Geometric mean results of hair-mercury concentrations $(\mu \mathrm{g} / \mathrm{g})$ from both surveys in regards to significant associations with responses to the dietary questionnaire*

Group

Number Mean hair-mercury

1. Do you eat about the same amount of whale meat and blubber as you did one year ago?

No, I eat less

219

2.09

Yes, about the same

255

No, more

10

2.95

2. How many times per month, do you think you have eaten whale for dinner, on average, in the past six months?

0

$0.1-0.4$

40

2.15

0.5

163

2.43

1.0

94

3.09

$1.5-2$

567

3.99

$\geq 3$

23

3. How big was your portion on average?

I have not been eating whale

$\leq 100 \mathrm{~g}$

Between 100 and $200 \mathrm{~g}$

132

About $200 \mathrm{~g}$

67

2.95 
Between 200 and $300 \mathrm{~g}$

$\geq 300 \mathrm{~g}$

18

4. Do you often eat dried whale meat?

No, I do not eat dried whale meat at all

No, I only eat dried whale meat on rare occasions

304

2.51

Yes, for dinner/supper

28

3.77

$* \mathrm{p}<0.01$ (one-way analysis of variance) 